IBIMA Publishing

IBIMA Business Review

https://ibimapublishing.com/articles/IBIMABR/2020/464307/

Vol. 2020 (2020), Article ID 464307, 14 pages, ISSEN: 1947-3788

DOI: $10.5171 / 2020.464307$

Research Article

\title{
Local Governments' Efficiency: Study of its Determinants
}

\author{
Nuno RIBEIRO ${ }^{1}$, Sónia P. NOGUEIRA ${ }^{2}$, Maria A. LINHARES ${ }^{3}$ and \\ Christian Luiz da SILVA ${ }^{4}$
}

\author{
${ }^{1}$ Management Applied Research Unit (UNIAG), Instituto Politécnico de Bragança, Campus de Santa \\ Apolónia, Bragança, Portugal \\ 2,3 Instituto Politécnico de Bragança, Campus de Santa Apolónia, Bragança, Research Center in \\ Political Science \\ ${ }^{4}$ Department of Management and Economics, Federal Technological University of Paraná, Campus \\ Curitiba, Paraná, Brazil
}

Correspondence should be addressed to: Nuno RIBEIRO; nunoa@ipb.pt

Received date: 2 May 2019 ; Accepted date: 16 January 2020 ; Published date: 2 June 2020

Copyright (C) 2020. Nuno RIBEIRO, Sónia P. NOGUEIRA, Maria A. LINHARES and Christian Luiz da SILVA. Distributed under Creative Commons Attribution 4.0 International CC-BY 4.0

\begin{abstract}
Public administration efficiency is increasing on the agenda, considering the scarcity of public resources and the greater demand of citizens for their needs to be met. This research aims to study the determinants of the financial efficiency of the Portuguese municipalities. For this , the determinants were grouped into three categories: sociodemographic, political and budgetary. There seems to be evidence, considering the results, that political determinants do not influence the financial efficiency of municipalities. Regarding the sociodemographic determinants, it is observed that the financial efficiency of the municipalities is influenced by location, purchasing power index, tourism and the unemployment rate. Tax revenue and financial independence are budgetary determinants that positively influence the financial efficiency of municipalities. Staff expenditure have a negative effect on it.
\end{abstract}

Keywords: Financial efficiency, Local governments' efficiency, Municipalities, Determinants.

Cite this Article as: Nuno RIBEIRO, Sónia P. NOGUEIRA, Maria A. LINHARES and Christian Luiz da SILVA (2020)," Local Governments' Efficiency: Study Of Its Determinants ", IBIMA Business Review, Vol. 2020 (2020), Article ID 464307, DOI: 10.5171/2020.464307 


\section{Introduction}

The efficient use of public financial resources is a constant concern in society, and this requires public managers to provide services that meet the basic needs of the population. Costs should be reduced without changing the quality of the services offered/provided to citizens.

The situation of financial imbalance, that has occurred in several municipalities highlights the need to analyse the allocation of public financial resources, as well as the study of the financial condition of municipalities. Therefore, it will be necessary to carry out analyses related to the size of public expenditure and studies that can verify whether the principles of efficiency, effectiveness and economy are being practised. It will be essential, still in the planning stage, that information about the financial condition of the municipalities can be made available, so as to allow guiding public managers to make decisions regarding the allocation of public financial resources (Souza, Andrade and Silva, 2015).

The analysis of governments efficiency in the generation of well-being is even more necessary when an increasing number of countries and governments are confronted with the progressive scarcity of financial resources. Considering the increase in transfers and competences from the central government to local governments, municipalities are increasingly responsible for maintaining and improving the goods and services available to them, because they are closer to the population.

Considering the previous framework, this research aims at identifying the factors that determine the financial efficiency of small Portuguese municipalities (approximately $55 \%$ of the total) in the period between 2008 and 2016, since there is non-statistical evidence that those will be the least efficient. For this purpose, the factors were grouped into three categories: sociodemographic, political and budgetary.

The panel data methodology is used. The data were obtained from different databases: Directorate-General of Local Authorities (DGAL), Portal Autárquico website, Base de Dados Portugal Contemporâneo (PORDATA), National Statistical Institute (INE), National Election Board (CNE) and the website of the National Program for Territorial Cohesion.

Besides this introduction, this study is organised in three sections. Section 2 presents the literature review on the factors that determine the efficiency of municipalities. Section 3 presents the empirical study, more specifically the objective, the research hypotheses, the dependent variable, how the data will be treated, the analysis and presentation of the results, as well as the discussion of the hypotheses. The work ends in section 4, where the conclusions of the study are presented.

\section{Determinants Of Municipal Efficiency}

According to the theoretical and empirical literature, a broad set of possible socioeconomic, political, institutional, demographic and budgetary determinants is identified in order to explain the financial efficiency of municipalities.

Van Den Eeckaut, Tulkens and Jamar (1993) conducted a study where the efficiency determinants of 235 Belgian municipalities were analysed. For the analysis of the data, non-parametric models (Data Envelopment Analysis - DEA and Free Disposal Hull FDH) were applied. The results showed that higher tax revenues and education levels positively affect the financial efficiency of municipalities. Efficiency is negatively affected by the increase in the purchasing power index and the value of intergovernmental subsidies.

Similarly, De Borger and Kerstens (1996) also analysed the factors that determine the efficiency of local governments in Belgium. The methodology was based on the application of non-parametric (DEA and FDH) and parametric models of deterministic and stochastic frontiers. The results showed that, while the central 
government transfers negatively affect efficiency levels, such as per capita revenue and social support subsidies; taxes and population density positively affect efficiency.

Balaguer-Coll, Prior and Tortosa-Ausina (2004) analysed the efficiency and the factors that determine it, having the municipalities of the Valencian community as population. For this, the authors applied the DEA technique as a methodology. The results showed that the fiscal policy (tax revenues) and intergovernmental subsidies are negatively related to municipal efficiency, whether it is under the control of local governments or not. The authors also concluded that large municipalities and the form of governance (minority government) are more efficient. Empirical evidence was also found to corroborate the hypothesis, that municipalities governed by a minority contribute to increasing financial efficiency.

In order to study the cost effectiveness of the provision of basic welfare services in the period from 1994 to 2002 in 353 Finnish municipalities, Loikkanen and Susiluoto (2005) used the DEA technique and performed a Tobit-type regression analysis. The results show that small municipalities in southern Finland show a higher level of municipal financial efficiency. Conversely, the least efficient municipalities are located in the peripheral areas in the north side of the country. The authors also found that higher revenues, a diversified structure of services and higher values of government subsidies tend to decrease the level of efficiency of municipal service delivery. The results also showed that the employees of municipalities between the ages of 35 and 49 and the population density seem to positively affect efficiency. Political variables and electoral cycles did not allow the authors to explain the differences in municipal financial efficiency. The size of the municipality and the high unemployment rate appear to have a negative impact on municipal financial efficiency. Higher education levels affect municipal financial efficiency positively.

Geys, Heinemann and Kalb (2007) also studied the efficiency level of 1.021 German municipalities. For this purpose, they used the parametric method of stochastic frontier. The results showed that municipalities with less population increase the per capita costs of the public service provided. That is, municipalities with higher population density tend to be more efficient.

Afonso and Fernandes (2008) focused on evaluating the efficiency of public expenditure in 278 Portuguese municipalities (mainland), through the application of the DEA technique. They demonstrated that socioeconomic factors such as the higher education level, the purchasing power index and geographical distance of the district from the capital influence the performance of municipalities in providing services and positively contribute to increasing municipal financial efficiency. Population density has a positive and significant effect on the population studied, since a larger number of inhabitants can facilitate the organization and the consumption of local services.

Balaguer-Coll and Prior (2009) sought to show if the inefficiencies of Spanish municipalities are due to external factors or to poor management by local governments. The sample studied was composed of 278 Spanish municipalities and the authors applied the DEA technique. The results showed that municipalities with a greater capacity to collect revenues from tax collection or intergovernmental transfers tend to manage resources inefficiently. Conversely, the greater the activity performed in the municipalities, the more pressure local governments feel to improve efficiency levels, allowing the authors to conclude that the level of activities provided has a positive impact on municipal financial efficiency levels.

Catalan and Ballve (2009) also analysed the efficiency of public expenditure in 1,686 municipalities in Peru. They used DEAConstant Returns to Scale (DEA-CRS) and DEA-Variable Returns to Scale (DEA-VRS) as nonparametric methods of analysis; as well as FDH and two parametric techniques (deterministic and stochastic). The results indicated that municipalities could achieve the same provision of municipal goods and 
services with $57.6 \%$ less financial resources. They identified the high holdings of the municipal common fund as factors, with a negative impact on Peruvian municipal financial efficiency,.

Faria, Farias, Santos, Ferreira and Silva (2012) addressed the determinants of efficiency and the relationship between the quality of life in 173 municipalities in the state of Minas Gerais, Brazil. The method used was the DEA technique and the linear regression model. The results showed that the volume of resources collected by municipalities is not proportional to the increase in efficiency in promoting the quality of life of the population. Correlations of per capita revenues variables in health and education did not reveal statistically significant results. The more revenue from taxes, the higher the inefficiency of the municipality in managing and allocating them. Thus, the smaller it is for their financial performance in promoting quality of life.

The efficiency of Chilean local governments and their determinants was studied by Pacheco, Sánchez and Villena (2013). Through the analysis of stochastic frontiers and panel data, the authors concluded that Chilean municipalities have a significant level of inefficiency. An increase in population, a longer distance from the municipality to the regional capital, a greater dependence on the municipal common fund in relation to revenues and a greater political concentration at the local level would increase efficiency in meeting needs in terms of education, health, garbage collection, access to drinking water and maintenance of green areas. The authors also found that the fact that the ruling party coincides with the central government party does not seem to have a significant effect on the municipal efficiency level.

Carosi and Ravagli (2014) focused on the study of the efficiency of the public expenditure of 285 Italian municipalities in the Tuscany region, through the application of the DEA methodology and a Tobit regression. They concluded that the size of the municipality affects the efficiency of public expenditure. That is, the larger the size of the municipality, the higher the level of efficiency of public expenditure.

Likewise, Otsuka, Goto and Sueyoshi (2014) investigated the financial efficiency of 47 Japanese municipalities in the period from 1980 to 2010. They used the DEA technique. The results indicated that fiscal transfers and the population significantly influence the degree of efficiency of municipalities. Small municipalities tend to be the least efficient.

Sevilla and Gomez (2015) measured relative efficiency in the provision of goods and services in the municipalities of Castilla la Mancha with more than 1.000 inhabitants, from 2001 to 2005. The DEA technique was applied to process the data. The results allowed to conclude that the size of the municipalities estimated by the number of inhabitants has a positive impact on efficiency.

Yusfany (2015) studied the efficiency and the influencing factors in the municipalities of Indonesia, from 1999 to 2012, using the DEA technique. The author found that municipalities with higher population density positively affect efficiency. Also the degree of fragmentation of political parties has a positive and significant effect on the efficiency of municipalities. Conversely, fiscal transfers have a negative effect on municipal financial efficiency.

Cantador (2017) evaluated the efficiency of the supply of public goods and services in 278 Portuguese municipalities (Mainland), in the period from 2009 to 2014. For the study, the nonparametric analysis DEA and FDH, and a time dependent conditional efficiency model were used. The results allowed the author to conclude that population density and socioeconomic factors do not have a significant influence on the efficiency of municipalities. He indicated the existence of a positive and significant relationship between the location of the municipalities (located in the coastal zone of the country) and the municipal efficiency. According to the author, municipalities located in the coastal zone of Portugal have the possibility of achieving higher levels of economic efficiency due to the high level of 
development and the greater capacity to increase their tax revenues.

Saraiva (2017) studied the relative efficiency of municipal expenditure by functions. The author performed an analysis using the DEA technique in order to understand if the municipal decisions regarding the allocation of their financial resources lead to the expected result efficiently. The obtained results evidenced a great variability in the levels of efficiency in relation to the groups of municipalities and the functions of the expenditure analysed. The groups of medium-sized municipalities, located on the coast in the Algarve, the Metropolitan Area of Lisbon and the Autonomous Region of Madeira, show efficiency levels above national averages.

Cordero, Caro and Fernandez (2017) measured and quantified the overall efficiency of 154 medium-sized Catalan municipalities between 2005 and 2012 . They used FHD as the analysis technique. The results show that, during the years of economic growth (period 2010-2012), municipalities showed a decrease in levels of financial efficiency. Variables representing the socioeconomic context have a significant effect on municipal financial efficiency. The study also shows that the efficiency levels of municipalities with larger populations are higher than the others. That leads to conclude that grouping large municipalities can help providing more efficient services. Population density has a positive and significant effect on financial efficiency, as well as tourism. The variable municipal debt did not obtain results with statistical significance.

In summary, and taking into account the literature review, there is a clear importance attributed to socioeconomic and demographic factors as determinants of municipal efficiency, such as, for example, the higher education level, the purchasing power index, the location, the geographical distance from the municipality to the district capital and the population density. Large municipalities show higher levels of efficiency.
The financial factors (tax revenues) are increasingly repeated in the different studies among the most discussed determinants of municipal financial efficiency.

Among other explanatory factors of municipal financial efficiency are the political factors; including the political ideology of the mayor and the coincidence of the party that governs the municipality and the party that heads the central government.

\section{Empirical Study}

\section{Objective and research hypotheses}

Municipalities have a constant need to present a good financial efficiency, as a guarantee for the fulfillment of their competences, which will allow them to satisfy the collective needs of citizens.

In this context, an in-depth knowledge is essential for this subject, which will allow municipal managers to adopt policies and make decisions that will make them solidify municipal financial efficiency. As such, the knowledge of its determinants will proactively help municipal officials adjust and improve their decisions for better financial efficiency.

This research aims to identify the factors that determine the financial efficiency of small Portuguese municipalities. Approximately $55 \%$ of the Portuguese municipalities will be studied in the period from 2008 to 2016, since they are considered to be the least efficient.

In order to achieve the defined objective and based on the literature review carried out, which allowed the identification of a set of factors that are related to municipal financial efficiency, the socio-demographic (related to social, demographic and economic area), political and budgetary research hypotheses are presented below.

HI: The size of the municipality positively/negatively influences its financial efficiency. 
$\mathrm{HI}_{2}$ : Financial efficiency is lower in municipalities with greater tourism capacity.

$H_{3}$ : The fact that the municipality is located on the coast positively/negatively influences the financial efficiency.

HI: Financial efficiency is lower in municipalities with higher illiteracy rates.

HI5: The higher the revenue (as seen in the purchasing power index) of citizens, the greater/smaller the financial efficiency will be.

HI6: The higher the unemployment, the lower the financial efficiency of the municipalities.

HI7: Financial efficiency is higher in municipalities governed by right-wing parties.

$H_{8}$ : Financial efficiency of the municipalities is greater in the municipalities that are governed by a majority government.

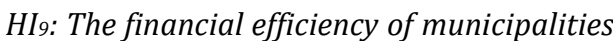
is greater when the president is reelected.

$H_{10}$ : Financial efficiency is higher/lower in municipalities where political rotation has occurred.

HI11: Financial efficiency is greater in municipalities that charge more tax revenues.

H112: Financial efficiency is higher in municipalities that have greater financial independence.
HI13: Financial efficiency is higher in municipalities that have more Central Administration transfers.

HI 14: Financial efficiency is higher/lower in municipalities with higher investment.

HI $_{15}$ : Financial efficiency is lower in municipalities with higher capital expenditure.

HI16: Financial efficiency is lower in municipalities with higher staff expenditure.

\section{Dependent Variable}

Given that, this paper intends to study the determinants of the financial efficiency of the Portuguese municipalities. A financial efficiency index will be used as the dependent variable of the model, which will be calculated based on the method presented by Carvalho et al. (2018). In this sense, the index is adapted according to the methodology presented below.

The index consists of 10 indicators. The maximum score of 308 points will be awarded to the municipality that presents the best ratios or value, with one point reduced for each municipality in a descending order. In the event of a tie, the same score will be granted, deducting the points of the municipalities tied up until the next municipality in the ranking order. It should be noted that the best ratio or value for some indicators is the highest while it is the lowest for others, as shown in Table 1. 
Table 1: Indicators for the calculation of the financial efficiency index

\begin{tabular}{|c|c|c|c|}
\hline Indicator & Formula & Source & Score Order \\
\hline \multirow{2}{*}{$\begin{array}{l}\text { Trading income less depreciations and } \\
\text { provisions on operating income }\end{array}$} & $\begin{array}{l}\text { Operating income - (operating costs - } \\
\text { depreciations - provisions) }\end{array}$ & \multirow{2}{*}{$\begin{array}{c}\text { Revenue } \\
\text { Statement } \\
\text { (Portal autárquico) }\end{array}$} & \multirow{2}{*}{ Higher ratio $=308$} \\
\hline & Operating income & & \\
\hline \multirow{2}{*}{ Liability per capita } & Liability & $\begin{array}{c}\text { Balance } \\
\text { (Portal autárquico) }\end{array}$ & \multirow{2}{*}{ Lower ratio $=308$} \\
\hline & Number of inhabitants & INE & \\
\hline Average payment period (APP) & APP on 31st December (number of days) & Portal autárquico & Lower ratio $=308$ \\
\hline \multirow{2}{*}{ Sustainability } & Expenditure paid & \multirow{2}{*}{ Portal autárquico } & \multirow{2}{*}{ Lower ratio $=308$} \\
\hline & Collected revenues & & \\
\hline \multirow{2}{*}{ Flexibility } & Expenditure on groupings $01,02,03$ and 10 & \multirow{2}{*}{ Portal autárquico } & \multirow{2}{*}{ Lower ratio $=308$} \\
\hline & Current revenue & & \\
\hline \multirow{2}{*}{ Vulnerability } & Expenditure paid & \multirow{2}{*}{ Portal autárquico } & \multirow{2}{*}{ Lower ratio $=308$} \\
\hline & Collected revenues - transfers & & \\
\hline \multirow{2}{*}{ Financial autonomy } & Equity capital & \multirow{2}{*}{$\begin{array}{c}\text { (Balance) } \\
\text { Portal autárquico }\end{array}$} & \multirow{2}{*}{ Lower ratio $=308$} \\
\hline & Assets & & \\
\hline \multirow{2}{*}{ Solvency } & Equity capital & \multirow{2}{*}{$\begin{array}{c}\text { (Balance) } \\
\text { Portal autárquico }\end{array}$} & \multirow{2}{*}{ Lower ratio $=308$} \\
\hline & Assets & & \\
\hline \multirow{2}{*}{ Direct taxes by inhabitants } & $I M I+I M T+I U C+$ Derrama & \multirow{2}{*}{ Portal autárquico } & \multirow{2}{*}{ Higher ratio $=308$} \\
\hline & Number of inhabitants & & \\
\hline \multirow{2}{*}{ Financial independence } & Own resources & \multirow{2}{*}{ Portal autárquico } & \multirow{2}{*}{ Higher ratio $=308$} \\
\hline & Revenues & & \\
\hline
\end{tabular}

Caption: IMI - Municipal Property Tax; IMT - Real Estate Transfer Municipal Tax; IUC - Road Tax; Derrama

- municipal tax applicable to the taxable revenue of each company

Source: Authors

The sum of the score of the 10 indicators, per year, will be translated into the value of the financial efficiency index, which could present a maximum of 3.080 points.

\section{Statistical Analysis}

To achieve the objective of this study, a panel data analysis will be carried out. As Ribeiro and Jorge (2015) refer, this type of analysis is appropriate to this study, considering that it will allow simultaneous analysis of intermunicipalities variations (sectional dimension) and over time (temporal dimension) variations, in this case, in the chronological period of 2008 to 2016.

Considering the hypotheses formulated, the following model is presented to be estimated:

finan_effic $=\beta_{0}+\beta_{1}$ size $+\beta_{2}$ tour $+\beta_{3}$ loc $+\beta_{4}$ illiter $+\beta_{5} \mathrm{ppi}+\beta_{6}$ unempl $+\beta_{7} \mathrm{pol} \_\mathrm{ideol}+\beta_{8} \mathrm{f} \_\mathrm{gov}+\beta_{9}$ reel + $\beta_{10}$ pol_rot $+\beta_{11}$ tax_revpc $+\beta_{12}$ fin_ind $+\beta_{13} \mathrm{CA} \_$transpc $+\beta_{14}$ invpc $+\beta_{15}$ cap_expendpc + $\beta_{16}$ staff_expendpc $+u_{i t}$

The final model will be based on the results obtained from the estimation by the PCSE method, considering the methodology presented by Aparicio and Márquez (2005).

\section{Presentation and Results Analysis}

Descriptive Analysis of Financial Efficiency
Table 2 presents the evolution of the financial efficiency index for all municipalities (308), due to several variables (size, location, form of governance, political ideology, rotation and financial independence), which allows to verify, in a descriptive way, the possibility of being influenced by them.

As far as the size is concerned, there seems to be a trend, in all the years of the analysis, that 
the larger municipalities are those with the highest average of financial efficiency index. It is observed that large municipalities have averages above those of medium size, and the latter have higher averages in relation to small municipalities.

There seems to be evidence that the size of the municipality influences financial efficiency; a fact that will be evaluated in the multivariate analysis.

The municipalities located on the coast show higher averages than those of the inland, so there seems to be evidence that the location of the municipality on the coast influences municipal financial efficiency positively.

Regarding the form of governance, the study found that in all the years under study, the municipalities governed in minority present, on average, better financial efficiency,. There seems to be a greater scrutiny in these municipalities, which leads municipal officials to have a more rigorous and efficient management.

As for the political ideology, it is observed that there is no trend during the period, as the values in the municipalities with a minority or majority government are very similar. So, it appears that financial efficiency is not influenced by political ideology.

Throughout the period of analysis, the municipalities where there was no political rotation present a financial efficiency superior to the municipalities in which it occurred. Political stability seems to contribute to a better financial efficiency; a fact that will be studied in the multivariate analysis.

Finally, based on the financial independence and considering the entire period of analysis, the financial efficiency average values seem to leave no doubt that those who are independent are more financially efficient than those who are not. 


\section{Table 2: Financial efficiency index}

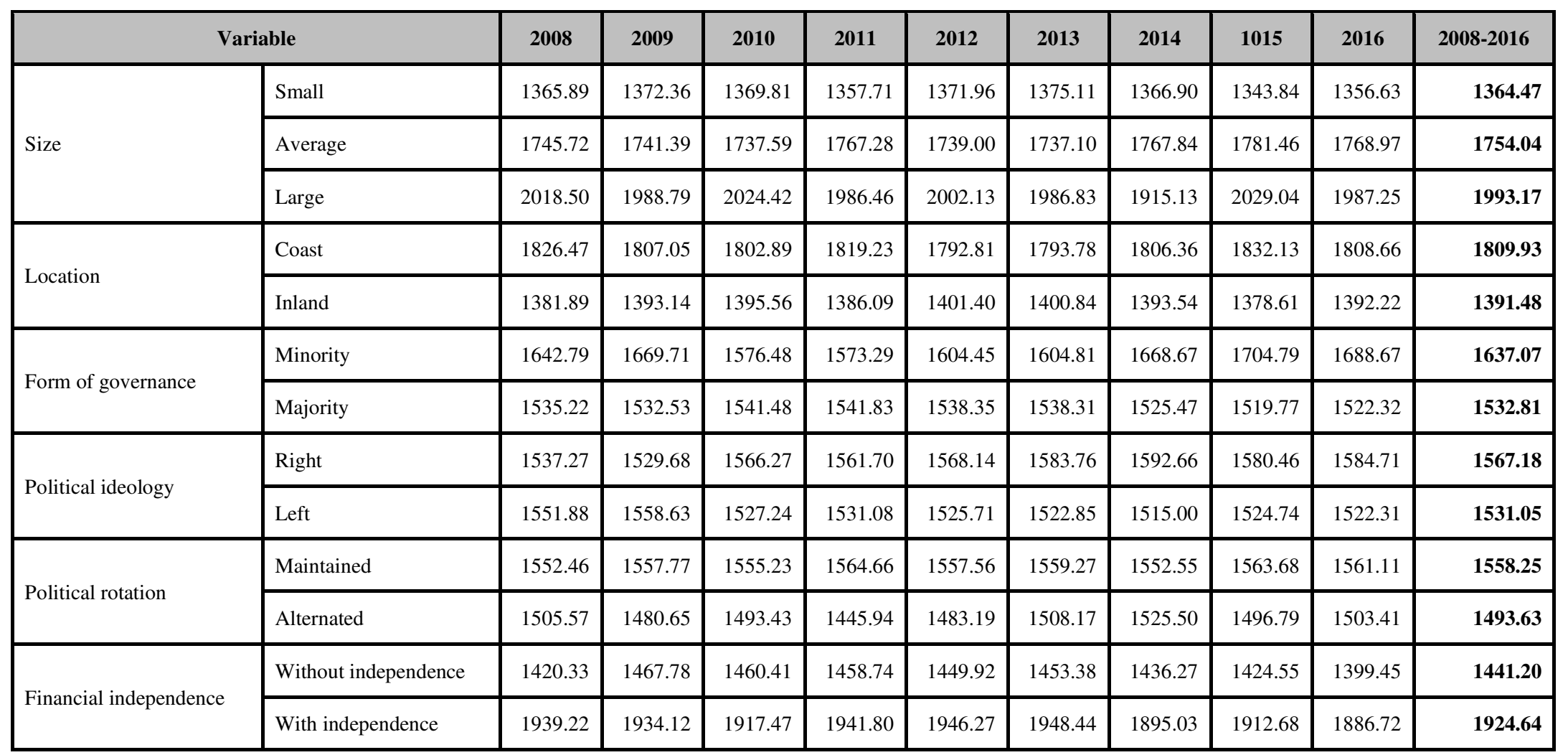

Source: Authors 


\section{Multivariate Analysis}

In order to test the established hypotheses, the multivariate analysis begins with the estimation of the model. It should be noted that the F and Wald tests results (Table 3 ) show, for all estimation methods, that the null hypothesis can be rejected for a significance level of $1 \%$ and that the independent variables do not explain the dependent variable. In this context, it can be said that the independent variables, as a whole, explain the financial efficiency of small Portuguese municipalities.

The Breusch and Pagan test was applied in order to understand if the unobservable individual effects are relevant to the explanation of the financial efficiency of the municipalities. The results allow to reject the null hypothesis (significance $=0.000$ ), and it can be considered that the individual nonobservable effects are relevant in determining the model. In this way, it can be confirmed that it will be preferable to use the estimation made through the random effects model rather than the OLS.

The $\mathrm{F}$ test was also carried out in order to evaluate the possibility that some dichotomous variables may belong to the model of explanation of the financial efficiency of small municipalities. The results (significance $=$ 0.000) confirm this idea and therefore, the fixed effects model must be used.

Since both; the random effects method and the fixed effects method are preferable to the OLS model, the Hausma test was used to decide which one to use. The test results show, as for all municipalities, that the null hypothesis ( significance $=0.000)$, which indicates the unobserved individual effects are not correlated with the explanatory variables, is rejected. In this sense, it will also be necessary to use fixed effects estimation for small municipalities, since it is the most appropriate.
The Pesaran, Wooldridge and modified Wald tests, which allow to evaluate the possibility of the existence of contemporary correlation, autocorrelation and heteroscedasticity, showed results that allow the study to verify that the estimation by the fixed effects method presents three problems, for which it was estimated using the FGLS and PCSE models.

Taking into account that the results of the PCSE model are more robust than those of the FGLS (Table 3), the latter are emphasised. The explanatory power of the model is relatively good, since it verified that the independent variables with statistical significance explain $44.8 \%\left(R^{2}=0.448\right)$ of the variation observed in the financial efficiency of small municipalities.

The explanatory variables of municipal financial efficiency are, in this case, tour, loc, ppi, unempl, tax_revpc, fin_ind and staff_expendpc. The variables 'municipality size' and 'investment expenditure' do not present statistical significance, but the variable 'tourism capacity' does explain the financial efficiency of small municipalities. It should be noted that the estimation results for the variables that are significant, jointly in both models, present the same relation signs. Thus, the relationship between coastal location, purchasing power index, tax revenue and financial independence, is positive and statistically significant, with a significance of $5 \%, 5 \%, 1 \%$ and $1 \%$, respectively. The variables 'unemployment' and 'staff expenditure ', with a significance of $1 \%$, also present a negative and statistically significant relation with the financial efficiency of small municipalities. The variable 'tourism capacity', which is revealed in this model to be statistically significant, also presents a negative relation. 
Table 3: Result of the estimation of the panel data model for small municipalities

\begin{tabular}{|c|c|c|c|c|c|c|c|c|c|c|}
\hline \multirow{2}{*}{ Variable } & \multicolumn{2}{|c|}{$O L S$} & \multicolumn{2}{|c|}{ Random Effects } & \multicolumn{2}{|c|}{ Fixed Effects } & \multicolumn{2}{|c|}{$F G L S$} & \multicolumn{2}{|c|}{ PCSE } \\
\hline & Coefficient & $T$ & Coefficient & $T$ & Coefficient & $t$ & Coefficient & $t$ & Coefficient & $t$ \\
\hline size & & & $1387.016^{* * * *}$ & (16.377) & & & & & & \\
\hline tour & $-2.298 * *$ & $(-2.674)$ & -1.310 & $(-1.602)$ & -0.988 & $(-1.145)$ & -1.709 & $(-1.952)$ & $-1.752 *$ & $(-2.082)$ \\
\hline loc & $67.619^{* *}$ & -3.012 & 71.320 & $(1.476)$ & & & 42.959 & $(1.562)$ & $67.658 * *$ & $(2.882)$ \\
\hline illiter & -3.701 & $(-1.760)$ & -2.858 & $(-0.639)$ & & & -1.538 & $(-0.576)$ & -3.304 & $(-0.984)$ \\
\hline ppi & $2.792 * * *$ & $(4.876)$ & $2.782 * * *$ & (3.367) & 1.200 & $(1.088)$ & $3.171^{* * * *}$ & $(4.794)$ & $3.303 * *$ & (3.253) \\
\hline unempl & $-2197.212^{* * * *}$ & $(-6.777)$ & -1607.497 *** & $(-4.655)$ & $-1236.963 * *$ & $(-3.259)$ & $-1811.327^{* * *}$ & $(-5.478)$ & $-1813.552 * * *$ & $(-3.598)$ \\
\hline pol_ideol & 10.819 & $(0.830)$ & 1.005 & $(0.092)$ & -0.108 & $(-0.010)$ & 11.828 & (1.007) & 9.006 & $(0.767)$ \\
\hline f_gov & -32.861 & $(-1.361)$ & 0.125 & $(0.006)$ & 2.928 & $(0.127)$ & -9.145 & $(-0.395)$ & -16.357 & $(-0.640)$ \\
\hline reel & 17.916 & $(1.210)$ & $38.124 * *$ & (3.202) & $41.757 * * *$ & $(3.441)$ & 9.101 & $(0.665)$ & 17.883 & (1.174) \\
\hline pol_rot & $-47.120 * *$ & $(-2.697)$ & 21.379 & $(1.342)$ & 32.201 & $(1.947)$ & $-34.797^{*}$ & $(-2.050)$ & -28.917 & $(-1.081)$ \\
\hline tax_revpc & $0.245^{* * *}$ & $(9.500)$ & $0.251 * * *$ & $(7.541)$ & $0.366^{* * *}$ & $(6.923)$ & $0.296^{* * *}$ & $(9.361)$ & $0.224 * * *$ & $(6.534)$ \\
\hline fin_ind & $231.578 * * *$ & $(8.417)$ & $126.865 * * *$ & $(4.848)$ & $103.645 * * *$ & $(3.767)$ & $145.870^{* * * *}$ & $(5.811)$ & $163.341^{* * *}$ & (4.886) \\
\hline CA_transpc & 0.001 & $(0.030)$ & -0.020 & $(-0.717)$ & -0.029 & $(-0.891)$ & 0.002 & $(0.082)$ & -0.014 & $(-0.509)$ \\
\hline invpc & -0.016 & $(-0.413)$ & $-0.085^{*}$ & $(-2.529)$ & $-0.097 * *$ & $(-2.769)$ & $-0.093 * *$ & $(-2.886)$ & -0.082 & $(-1.922)$ \\
\hline cap_expendpc & 0.010 & $(0.415)$ & 0.034 & $(1.641)$ & 0.036 & $(1.701)$ & $0.041 * *$ & $(2.720)$ & 0.031 & $(1.682)$ \\
\hline staff_expendpc & $-0.452 * * *$ & $(-9.719)$ & $-0.429 * * *$ & $(-7.659)$ & $-0.334 * * *$ & $(-4.426)$ & $-0.499 * * *$ & $(-9.737)$ & $-0.411 * * *$ & $(-5.651)$ \\
\hline _cons & $1457.791 * * *$ & $(24.593)$ & & & $1394.763^{* * *}$ & $(16.293)$ & $1384.799 * * *$ & (21.156) & 1387.557 *** & $(13.38)$ \\
\hline Observations & 1620 & & 1620 & & 1620 & & 1620 & & 1620 & \\
\hline $\mathrm{R}^{2}$ & 0.311 & & 0.400 & & 0.071 & & & & 0.448 & \\
\hline Wald $\left(X^{2}\right)$ & & & $9806.93 * * *$ & & & & $484.12 * * *$ & & $1194.03 * * *$ & \\
\hline Breusch\&Pagan & & & $1464.26 * * *$ & & & & & & & \\
\hline$F$ & 48.20 *** & & & & $10.26 * * *$ & & & & & \\
\hline Hausman $\left(X^{2}\right)$ & & & $39.78 * * *$ & & & & & & & \\
\hline
\end{tabular}

(1) The Breusch \& Pagan test has a $\chi^{2}$ distribution and tests the null hypothesis that the unobservable individual effects are irrelevant to the explanation of the dependent variable, against the alternative hypothesis of relevance for the explanation of the dependent variable. (2) The Hausman test has a 22 distribution and tests the null hypothesis that unobservable individual effects are not correlated with explanatory variables against the null hypothesis of correlation hypothesis of joint significance of the parameters of the explanatory variables. (4) The F Test has normal distribution $N(0.1)$ and tests the null hypothesis of joint non-significance of the estimated parameters, against the alternative hypothesis of joint significance of the estimated parameters. $(5) *$ Statistical significance of $10 \%$; * Statistical significance of $5 \%$; *** Statistical significance of $1 \%$

Source: Authors

Nuno RIBEIRO, Sónia P. NOGUEIRA, Maria A. LINHARES and Christian Luiz da SILVA (2020), IBIMA Business Review, DOI: 10.5171/2020.464307 
It must be said that none of the political variables, such as 'ideology', 'form of governance', 'reelection of the president of the municipal executive' and 'political rotation', presents statistical significance. However, considering the estimation sign, there seems to be some evidence, statistically unproven, that right-wing municipalities might be more efficient as well as in the circumstance of reelection of the president of the municipality. Contrarily, the rotation of the political party that governs the municipality seems to negatively influence the financial efficiency.

\section{Discussion of Hypotheses}

In this section, the hypotheses are discussed, considering the estimation results of the model. The analysis hereby starts with the research hypotheses associated to the sociodemographic variables.

Regarding the estimation results associated to the variable 'tourism', it is observed that they are significant. The relationship is negative, so that $\mathrm{HI}_{2}$ can be validated. This study confirms the opinion of Fernández and Jiménez (2002), who argue that the municipalities with more tourism may increase expenditure (e.g. provision of public services, such as cultural and artistic events, public transport and sanitation), not compensated by the increase in revenue, which may contribute to a decrease in financial efficiency.

Regarding the location, there is evidence that coastal municipalities present a better financial efficiency. This validates $\mathbf{H I}_{3}$, which allows to confirm the idea of Cantador (2017), Saraiva (2017) and Loikkanen and Susiluoto (2005) that location influences the financial efficiency of the municipalities.

The hypothesis related to Revenue Purchasing power index (ppi), is also corroborated, thus validating HI5. Although there were some initial doubts about this relationship, the result presented by De Borger and Kerstens (1996); that per capita revenue; in this case ppi positively affects financial efficiency, is valid.

The last sociodemographic hypothesis related to unemployment, is also validated (HI6). This study corroborate the opinion of Cordero et al. (2017), Loikkanen and Susiluoto (2005) and
Ribeiro and Jorge (2015), that greater social support from the municipality (e.g. social assistance and social housing) may influence financial efficiency negatively.

As far as political hypotheses are concerned, the results are not statistically significant. In this context, considering that even in the descriptive analysis there seemed to be evidence that some political variables influenced financial efficiency, no hypothesis can be validated. It can then be said that political ideology, the form of governance, reelection and political rotation do not influence the financial efficiency of small Portuguese municipalities.

The positive and significant relationship between financial efficiency and tax revenue seems to leave no doubt that $\mathbf{H I}_{11}$ should be validated. Therefore, in line with the idea of Van Den Eeckaut et al. (1993), De Borger and Kerstens (1996), Yusfany (2015) and Souza et al. (2015), the hypothesis that the increase of the fiscal revenue increases the financial efficiency of the municipalities, is validated.

Regarding the results obtained for the variable financial independence, it is observed that it presents significant statistics, thus allowing to validate $\mathbf{H I}_{12}$. As such, the positive sign of the coefficients indicates that the greater the financial independence, the greater the financial efficiency of the small municipalities will be, thus corroborating Mier's (2011) opinion.

Finally, significant empirical evidence was obtained to validate the hypothesis $\left(\mathrm{HI}_{16}\right)$ that financial efficiency is lower in municipalities with higher staff expenditure, as advocated by Cantador (2017) and Carvalho et al. (2018).

\section{Conclusions}

Through decentralization, municipalities have been playing a more decisive role in Public Administration, not only in terms of the organisation, but also in the provision of local public services. In this sense and given the importance and quantity of resources employed, there is an interest in determining the efficiency with which these resources are used in Portuguese municipalities. 
The literature has studied municipal efficiency, using various methods and techniques for this purpose. In the context of these studies, a number of factors have been analysed, which are likely to influence it, such as size, location, illiteracy rate, governance, political ideology, reelection, investments, capital spending and others.

This research aimed to identify the determinants of the financial efficiency of small Portuguese municipalities between 2008 and 2016.

The results obtained allow this study to conclude that, with regards to the sociodemographic determinants proposed as determinants of financial efficiency - size, tourism, location, purchasing power index and unemployment rate - these determinants generally have a statistically significant influence. The location and the purchasing power index have a positive impact on the financial efficiency of small Portuguese municipalities. In contrast, tourism and the unemployment rate have a negative influence on it.

Regarding the political determinants, it was found that the results are not statistically significant. In this sense, and considering the descriptive analysis with some evidence that some political variables influenced the municipal financial efficiency, it is not possible to validate any research hypotheses. It can thus be assumed that political ideology, governance, reelection and political rotation do not influence the financial efficiency of small Portuguese municipalities.

Regarding the budgetary determinants, tax revenue and financial independence positively influence the financial efficiency of small municipalities. Conversely, staff expenditure have a negative effect on it.

The results obtained can become a management tool, so that politicians and public managers can make better decisions which will promote financial efficiency in local governments.

\section{Acknowledgment}

UNIAG, R\&D unit funded by the FCT Portuguese Foundation for the Development of
Science and Technology, Ministry of Science, Technology and Higher Education. Project no. UIDB/04752/2020.

This study was conducted at the Research Center in Political Science (UIDB/CPO/00758/2020), University of Minho/University of Évora and supported by the Portuguese Foundation for Science and Technology (FCT) and the Portuguese Ministry of Education and Science through national funds.

\section{References}

- Afonso, A. and Fernandes, S. (2008)'Assessing and explaining the relative efficiency of local government,'The Journal of SocioEconomic, 37, 1946-1979.

- Aparicio, J. and Márquez, J. (2005)’Diagnóstico y espacificación de modelos panel en STATA 8.0., ' [Online][Retrieved September 28, 2010]http://investigadores.cide.edu/ap aricio/data/.

- Balaguer-Coll, M. and Prior, D. (2009)'Short-and long-term evaluation of efficiency and quality. An application to Spanish municipalities'Applied Economics, 41, 2991-3002.

- Balaguer-Coll, M., Prior, D., and TortosaAusina, E. (2004)'On the determinants of local government performance: a two stage nonparametric approach, 'European EconomicReview,51, 425-451.

- Cantador, E. (2017)'Financiación y eficiencia de los municipios portugueses,'Tesis Doctoral en Economia y Empresa,Universidad de Extremadura.

- Carosi, L. and Ravagli, L. (2014)'Global public spending efficiency in Tuscan municipalities,'Technical Report №. 175, Dipartimento di Economia $e$ Management (DEM), University of Pisa, Italy.

- Carvalho, J., Fernandes, M., Camões, P.,and Jorge, S. (2018)’Anuário Financeiro dos Municípios Portugueses - 
2017, Lisboa, Ordem dos Técnicos Oficiais de Contas.

- Cordero, J.; Caro, C.,and Fernandez, C. (2017)'Measuring efficiency in catalan municipalities using a dynamic conditional model, 'Applied Economics, $X X V(75), 29-51$.

- De Borger, B. and Kerstens, K. (1996)'Cost efficiency of belgian local governments: A comparative analysis of FDH, DEA and econometric approaches,'Regional Science andUrban Economics, 26, 145-170.

- Fernández, P. and Jiménez, D. (2002)'Análisis del Endeudamiento y Efectos de su Control en las Corporaciones Locales, ' IX Encuentro de Economía Pública, 7-8 febrero 2002, Vigo.

- $\quad$ Faria, L., Farias, E., Santos, L., Ferreira, M., andSilva, A. (2012)'Fatores determinantes para a eficiência alocativa de recursos públicos, a partir do índice de promoção da qualidade de vida nos municípios mineiros`Revista cesumar ciências humanas e sociais aplicadas,17(1), 143-172.

- Geys, B., Heinemann, F., and Kalb, A. (2007)'Local governments in the wake of demographic change: efficiency and economies of scale in german municipalities, 'ZEW - centre for european economic research,Discussion Paper № 07-036.

- Loikkanen, H. and I. Susiluoto $(2005)^{\prime}$ Cost efficiency of finnish municipalities in basic service provision 1994-2002.'Urban

Public EconomicsReview, 4, 39-64.

- Mier, M. (2011)'Endeudamiento y ciclo político-presupuestario: aplicación a los municipios asturianos, 'Presupuesto $y$ Gasto Público, 65(s.e.),75-95.

- Otsuka, A.; Goto, M., and Sueyoshi, T. (2014)'Cost-efficiency of japanese local governments: effects of decentralization and regional integration,'Regional Studies, regional science, 1(1), 207-220.

- Pacheco, F.; Sánchez, R., and Villena, M. (2013)'Eficiência de los gobiernos locales y sus determinantes: un análisis de fronteras estocásticas para municipalidades chilenas, 'Publicación de la dirección de presupuestos del ministerio de hacienda.

- $\quad$ Ribeiro, N. and Jorge, S. (2015)'Fatores explicativos do nível de endividamento dos municípios portugueses: uma análise de dados em painel, $X X V$ Jornadas Hispanolusas "Enfoques Empresariales de la Gestión Científica. Transferencia de Conocimiento a la Empresa,5-6 febrero 2015, Ourense, Espanha.

- Saraiva, P. (2017)’Eficiência das despesas por funções municipais: uma aplicação da data envelopment analysis, ’Dissertação de Mestrado em gestão das Organizações,Instituto Politécnico de Bragança.

- Sevilla, C. and Gómez, M.(2015)'La eficiencia municipal en la prestación de bienes y servicios público: de la medición de su nivel al análisis de sus posibles causas,'Tribuna de economia, 882, 157169.

- Souza, F.; Andrade, A., and Silva, M. (2015)'Eficiência na alocação de recursos públicos destinado ao ensino fundamental: um estudo da sua relação com a condição financeira de municípios brasileiros, 'Contexto, 15(31), 81-99

- Van Den Eeckaut, P.; Tulkens, H., and Jamar, M. (1993)'Cost efficiency in Belgian municipalities. Cost efficiency in Belgium municipalities,' In: Fried, H., Lovell, C., and Schmidt, S. (eds.), the measurement of productive efficiency: techniques and applications. Oxford university press, New York, 300-334.

- Yusfany, A. (2015)'The efficiency of local governments and its influence factors, International journal of technology enhancements and emerging engineering research, 4(10), 219-241. 